\title{
The Role of Spiritual-Based Leadership as Predictor in Improving Employee Performance
}

\author{
Siti Hidayah $\bowtie$, Sutopo \\ Management Department, STIE Dharmaputra Semarang, Semarang, Indonesia
}

\section{Info Article}

History Article:

Received Januari 2017

Approved Februari 2017

Published Maret 2017

Keywords:

Spiritual-Based Leadership;

Employee Performance; Workplace Spiritality.

\begin{abstract}
This study aims to develop the concept of spiritual-based leadership in solving the controversy of empirical research results. This leadership relies more on spiritual intelligence in its leadership activities, and maintains ethical values and divine values. The population is all employees who come from 13 Baitul Mal Wa Tamwil (BMT) in Semarang City. Samples is set at 100 people as respondents. The sample that is feasible to process is 79 samples. While the sampling technique is stratified sampling technique, then each sample is selected using random sampling. Testing of hypothesis is using linear regression analysis method with program SPSS Version 16.0. The results showed that the spiritual-based leadership has positive and significant effect on the employee performance at BMT in Semarang City proved acceptable. This means that spiritualbased leadership can be said to have a role as a predictor in improving employee performance. For the next, The reseach can develope to improve performance by another variable. The variable like another leadership style and spiritual motivation.
\end{abstract}

\section{Peran Kepemimpinan Berbasis Spiritual Sebagai Prediktor dalam Meningkatkan Kinerja Karyawan}

\begin{abstract}
Abstrak
Penelitian ini bertujuan untuk mengembangkan konsep kepemimpinan berbasis spiritual dalam memecahkan kontroversi hasil penelitian empiris. Populasi adalah seluruh karyawan yang berasal dari 13 Baitul Mal Wa Tamwil (BMT) di Kota Semarang. Sampel 100 orang. Sampel yang layak untuk diolah adalah 79 sampel. Sedangkan teknik pengambilan sampel adalah teknik stratified sampling, maka setiap sampel dipilih dengan menggunakan random sampling. Pengujian hipotesis menggunakan metode analisis regresi linier dengan program SPSS Version 16.0. Hasil penelitian menunjukkan bahwa kepemimpinan berbasis spiritual berpengaruh positif dan signifikan terhadap kinerja pegawai di BMT di Kota Semarang terbukti dapat diterima. Ini berarti bahwa kepemimpinan berbasis spiritual dapat dikatakan memiliki peran sebagai prediktor dalam meningkatkan kinerja karyawan. Kejujuran hati, keadilan, pengetahuan diri, fokus altruistik, spiritualisme non-dogmatis, bekerja lebih banyak efisien, menghasilkan yang terbaik dalam diri sendiri dan orang lain, keterbukaan menerima perubahan, disiplin, fleksibel, rileks, cerdas, dan rendah hati, sebenarnya ia memiliki kontribusi positif untuk meningkatkan kinerja karyawan. Pada penelitian selanjutnya dapat menambahkan variabel lain yang bisa meningkatkan kinerja seperti gaya kepemimpinan yang lain dan motivasi spiritual.
\end{abstract}

JEL Classification: M3, M31 


\section{INTRODUCTION}

Employee performance is the result or level of success of an employee as a whole during a certain period in performing the task compared with the standard results of work, targets or goals, as well as pre-determined criteria, and has been mutually agreed upon in the organization (Nanjundeswaraswamy \& Swamy, 2014). Employee performance is important to the organization in achieving organizational goals. Therefore, for the purpose of the organization can be achieved well, then organizations need to seek various factors to improve employee performance.

One factor that can be sought by the organization to improve employee performance is through the practice of leadership that is reliable (Fahmi, 2009). Leadership is an effort to influence follower activities (subordinates) through the communication process to achieve certain goals (Rawung, 2013). Buble et al. (2014) argues that leadership is a mean of achieving goals. What is meant in this case is the leader is someone who has a program and does the program together with members of the group through a certain way or style, so that leadership has a role as a dynamic force that encourages and coordinates the organization in achieving the established goals, namely good performance (Fahmi, 2009).

Evans (2007), Timothy et al. (2011), Mahdinezhad, et al. (2013) and Oweyemi (2014) states that leadership is one of the main contributing factors that can affect employee performance (Aydin, 2009). Leadership plays an important role in determining and improving employee performance because leadership roles will be needed to align different needs and also to create a conducive working environment. In addition, leadership can encourage employees to behave in accordance with the desired organizational goals, namely better work behavior (Hakim, 2011).

This is in line with Buble et al.' opinion (2014) that leadership factor has a very important role in improving employee performance because effective leadership can provide direc- tion to the efforts of all employees in achieving organizational goals.

Therefore, some researchers have conducted research about the influence of leadership on employee performance, among them are the first, first, Fahmi (2009) in his research proves that leadership or leadership style has a significant effect on the employee performance. Second, Kiswanto (2010) in his research proves that leadership has a positive and significant effect on the employee performance.

Third, Hakim (2011) in his research also proves that leadership or leadership style significantly influence on the performance of civil servants. Fourth, Purwanto (2012) in his research proves that leadership has a significant effect on the performance of agricultural field extension. Fifth, Soegihartono (2012) in his research proves that leadership factor has a significant effect on the employee performance. Sixth, Rawung (2013) in their research prove that leadership (transformational leadership, transactional leadership, and laissez-faire leadership) has a significant effect on the employee performance. The last, Naile (2014) in their research also prove that leadership has a positive and significant effect on employee performance.

Nevertheless, the results of these studies are in fact different from those of Aydin (2009) who examine about leadership styles, organizational culture, and performance at companies in the United Kingdom. The result of this study proves that leadership or leadership style is not directly related or in other words, there is no significant positive relationship with performance. This is because leadership or leadership styles applied in these companies are mostly task-oriented and job oriented so that the orientation of people (employees or subordinates) is very low. In addition, most of the leadership applied in these companies is oriented solely on the benefits of mere material, but less attention to the needs of the souls of employees or subordinates.

Based on the explanation, it can be said that there is still controversy or differences in empirical research results regarding the influence of leadership on performance, especially 
the performance of employees as described previously. In addition, there is still a phenomenon as argued by Frisdiantara (2012), that almost every concept of leadership in the world is a concept of leadership that has been taken from the secular and materialistic values that have developed in a competitive commercial world, where the concept of leadership only based on conventional wisdom and also based solely on sense, mind, and mind tools. Leadership can be good relationship from communication (Raharjo et al, 2016). Kaya (2015) also states that most researches on leadership are still lacking in depth about spirituality.

Therefore, to solve the controversy and phenomenon, so in this study proposed the development of the leadership concept, namely spiritual-based leadership. The spirituality here is something very closely related to the concept of the soul, thus defining a principle that the essence of life is not mere matter but its spiritual value (Frisdiantara, 2012). While spiritual-based leadership according to Kaya (2015) is a leadership that brings the worldly dimension to the divine dimension, and more relies on spiritual intelligence in leadership activities. Or in other words, spiritual-based leadership is a leadership that greatly maintains ethical values and divine values. By upholding ethical and divine values this leadership can lead to work activities and improve better performance.

Based on the above description it is necessary to investigate further about the role of spiritual-based leadership as a predictor in improving employee performance (empirical study at BMT in Semarang City).

\section{Hypothesis Development}

Spiritual-based leadership is leadership that brings worldly dimension to divine dimension, and more relies on spiritual intelligence in leadership activities. Spiritual-based leadership is also a leadership that greatly maintains ethical values and divine values (Kaya, 2015).

Research related to spiritual-based leadership on performance has been done by pre- vious researchers, one of which is Devi (2015) who examines the causal model of spiritual leadership theory that is between the quality of spiritual leadership, spiritual survival with commitment and work productivity of employees in the organization. The result provides strong support to spiritual leadership theory and measurement. The result proves that there is a positive and significant relationship between the quality of spiritual leadership, spiritual survival with the commitment and work productivity of employees in the organization. Spiritual leadership theory is a new paradigm for leadership theory, research, and practice that can broaden the theory of transformational and charismatic leadership through ethics and values based on theories.

Therefore, from the above description can be formulated research hypothesis that spiritual-based leadership has a positive and significant effect on employee performance. The higher the role of the spiritual-based leadership, the greater the performance of employees.

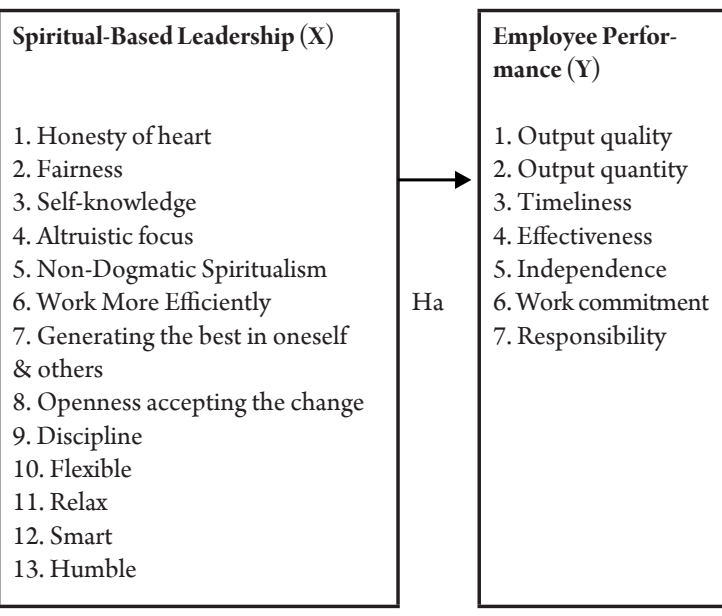

Figure 1. Framework Model

From the framework model above, it can be explained that employee performance can be influenced by spiritual-based leadership. Spiritual-based leadership as an independent variable in this study is expected to be a predictor in improving employee performance 


\section{METHOD}

The population in this study is all employees who come from 13 Baitul Mal Wa Tamwil (BMT) in Semarang City with the number of employees \pm 400 people (Association of BMT Central Java, 2014). The number of samples is 100 people taken $25 \%$ of the total population of $400 \times 25 \%=100$. So the number of samples is set at 100 people as respondents. While the sampling technique is using stratified sampling technique, then each sample is selected using random sampling, which is the sample selection method where members of the population get the same chance to be selected and if it is selected can not be selected again.

In this research there are two variables, namely one independent variable and one dependent variable. Independent variable is spiritual-based leadership, and dependent variable is the employee performance. Spiritual-based leadership is a leadership that brings worldly dimensions to the divine dimension, and more relies on spiritual intelligence in leadership activities. Spiritual-based leadership is also a leadership that greatly maintains ethical values and divine values (Kaya, 2015).

Leadership is the ability to use influence and motivate individuals to achieve an organizational goal (Buble et al., 2014). The ability to influence them will determine the way in which individuals to achieve work or performance. It is based on the opinion that a leader has authority in planning, directing, coordinating, and controlling individual behavior. Organizational leaders can influence the behavior of organizational members by creating organizational systems and processes that meet the needs of organizational members, both individual needs, group needs, and organizational needs (Thamrin, 2012).

Leadership is a process used by leaders to guide organizations and give examples of behavior toward followers (subordinates) (Aydin, 2009). Basically the purpose of leadership is to encourage work passion and high work productivity of individuals, in order to achieve ma- ximum organizational goals. Therefore, if the individual has been driven passion of work and productivity it is not impossible that his performance will increase (Soegihartono, 2012).

Spiritual-based leadership is measured by indicators: honesty of heart, fairness, selfknowledge, altruistic focus, non-dogmatic spiritualism, work more efficiently, generating the best in oneself and others, openness accepting the change, discipline, flexible, relax, smart, and humble.

Employee performance is the result or level of success of an employee as a whole during a certain period in performing tasks compared to pre-determined standards of work, targets or goals or criteria, and has been mutually agreed upon in the organization (Wany, 2014).

Tan (2011) said too that employee performance is a procedure that includes (1) setting standards for employee performance, (2) assessment of the actual performance of employee in relation to standards, (3) giving feedback to employee with the aim of motivating the employee to eliminate deterioration of performance or continue to perform even higher.

Melchar (2010) states that employee performance is as an achievement or ability of an employee covering elements of reliability, initiative, innovation, accuracy, work result, presence, attitude, cooperation, tidiness, quality of work, and others. The employee performance is to point to the employee performance of the assigned task. An employee is said to have a good performance when the employee has a good performance in the implementation of the tasks it carries. From the explanation, it seems clear that the performance of employees is related to the achievement of an execution of tasks or work performed by an employee.

Employee performance is measured by indicators: output quality, output quantity, timeliness, effectiveness, independence, work commitment, and responsibility(Aydin, 2009).

While the measurement that will be used in this research is using interval data measurement (Interval Scale). While the interval data measurement is using Agree-Disagree Scale. 
Siti Hidayah \& Sutopo / The Role of Spiritual-Based Leadership as...

This scale is another form of Bipolar Adjective, by developing statement that result in agreedisagree answers in various value ranges. STS $=$ Strongly Disagree is given a score of 1 TS $=$ Disagree is given a score of 2 $\mathrm{KS}=$ Less Agree is given a score of 3 $\mathrm{ST}=$ Agree is given a score of 4 SS $=$ Strongly Agree is given score 5

Sources of data in this study consist of primary data and secondary data. Primary data is information or data obtained directly from the respondents through the answers to the questionnaire. Primary data taken in this research is data about the responses of respondents related to spiritual-based leadership variables and employee performance variable. Secondary data is information or data obtained from the documentation, literature-literature related to the problem researched. Secondary data taken in this research is data about previous research relating to this research and data about the object studied which is obtained from BMT in Semarang City.

While the methods of data collection in this research are: Observation, namely the collection of data through observation directly to the object of research. The data obtained through this observation is the data about the object researched. Questionnaire, namely the collection of data through the provision of a list of questions/ statements filled by the respondent. Data obtained through this questionnaire is data about the responses of respondents related to the variables studied.

Library Studies, namely the collection of data obtained through literature or journals and previous research related to the problem researched. Hypothesis proposed in this study will be examined by using the method of linear regression analysis with SPSS version 16.0. The regression equation is as follows:

$$
\mathrm{Y}=\mathrm{bX}+\mathrm{e}
$$

Information:

$\mathrm{X} \quad=$ spiritual-based leadership

$\mathrm{Y} \quad=$ employee performance $\mathrm{b}=$ regression coefficient

e $\quad=$ error

\section{RESULT AND DISCUSSION}

The questionnaire distributed in this research is 100 copies and distributed according to the number of respondents in BMT Semarang City. The number of questionnaires returned to the researchers is 79 copies. The number of questionnaires of 79 copies is feasible to be processed/ analyzed. The following is the result of analysis of research data.

Based on the result of the description of respondent profile shows that male respondents are 47 people (59.5\%), while female are 32 people $(40.5 \%)$. For respondents age is the average of respondents aged between 21 years-50 years (91.5\%). For the education level of respondents is the average of respondents educated between SMA-S1 (95\%). For the working period of respondents is the average respondent has a working period between 1 year- 25 years $(94.8 \%)$.

For the status of respondents is the average of respondents are married as many as 50 people $(63.3 \%)$, while they are still single there are about 29 people $(36.7 \%)$. As for the organizational experience of respondents is the average of respondent has organizational experience as many as 56 people (70.9\%), while they have no organizational experience there were about 23 people (29.1\%).

Based on the result of the description of respondents' answers show that respondents who agree and strongly agree on the questions of spiritual-based leadership variables, namely $94 \%$, and the remaining $6 \%$ answer less agree and disagree. As for the answers about the questions of the employee performance variables, namely as many as $83 \%$ of respondents answer agree and strongly agree, while the remaining $17 \%$ answer less agree and disagree. The result of the description of respondent's answers show that the average respondents answer agree and strongly agree from the questions of both research variables, on the contrary there is not one 
respondent (0\%) who answers strongly disagree from the questions of both variables of the study.

Based on the result of validity test indicates that the indicators of spiritual- based leadership and employee performance variable are valid, because the value of $\mathrm{r}^{-}{ }_{\text {count }}$ from indicators of both variables is bigger than the value of $\mathrm{r}_{\text {table }}$ $=0.184$ with $\mathrm{a}=0.05$. Similarly, for the result of reliability test shows that the value of Cronbach Alpha is greater than 0.70 ( $\mathrm{r}$ standard), so it can be concluded is reliable. Based on the result of the classic assumption test, for the result of data normality test indicates that the data is normally distributed. As for the result of heteroskedastisitas test shows there is no heteroskedastisitas on the regression model so that the regression model is feasible to use.

Based on the result of coefficient of determination test obtained value of $\mathrm{R}^{2}$ is 0.329 , this shows that employee performance as dependent variable can only be explained by the variation of spiritual-based leadership variable as independent variable as many as $32.9 \%$ while the remaining $(100 \%-32.9 \%=67.1 \%)$ is explained by other causes outside of the unobserved model. While the result of the F test (Anova test) obtained the value of $\mathrm{F}_{\text {count }}$ is 37.670 with a significance of $0.000<0.05$. Because the significance or probability is much smaller than 0.05 , then this regression model can be used to predict the employee performance at BMT in Semarang City.

Result of hypothesis test from the influence of spiritual-based leadership on employee performance can be explained as follows:

Ho: $b=0$ : Spiritual-based leadership has no effect on employee performance.

Ho: $b>0$ : Spiritual-based leadership has a significant effect on employee performance.

Result of hypothesis test obtained $\mathrm{t}$ - $_{\text {count }}$ value of spiritual-based leadership variable is 6.138 with a significance of $0.000<0.05$, meaning that spiritual-based leadership significantly influence on the employee performance at BMT in Semarang City. Thus the research hypothesis proved accepted.
The result of regression analysis from the influence of spiritual-based leadership on employee performance shows that the regression coefficient (beta) $b=0.573$ so that can be compiled regression equation as follows: $\mathrm{Y}=$ $0.573 \mathrm{X}+\mathrm{e}$. Thus it can be known the influence of Spiritual-Based Leadership à Employee Performance or $b=0.573$ (positive). This means that spiritual-based leadership has a positive effect on employee performance. It can be interpreted that the better the spiritual-based leadership is applied the higher the employee performance.

Based on the result of the description of respondent profile indicates that employees at BMT in Semarang City are still dominated by male employees. For the average age of employees is between the ages of 21 years-50 years. This shows that employees at BMT in Semarang City can still be said in the productive age. For the average level of employee education is educated between SMA-S1. This indicates that employees at BMT in Semarang City are still quite adequate in terms of education, however need to be upgraded to higher education level. For the average employment period is between 1 year- 25 years.

This shows that employees at BMT in Semarang City have enough work experience. For employee status is the average they are married. This shows that employees at BMT in Semarang City have already many members of family. As for the organizational experience of employees is on average that they have ever organizational experience. This shows that employees at BMT in Semarang City have enough experience in socializing in the community.

Based on the result of the description of respondents' answers shows that employees agree and strongly agree with the indicators of spiritual-based leadership variable, namely about honesty of heart, fairness, self-knowledge, altruistic focus, non-dogmatic spiritualism, work more efficiently, generating the best in oneself and others, openness accepting the change, discipline, flexible, relax, smart, and humble. Similarly, employees also agree and strongly agree 
with the indicators of employee performance variable, namely the quality of work, the quantity of work, the timeliness of completing the job, the effectiveness of the job, independence in doing the job, commitment in completing the job, and responsibility on the job.

Based on the result of hypothesis testing shows that the spiritual-based leadership has a positive and significant effect on employee performance is proven acceptable. This result is proved by the output of $\mathrm{t}$ - ${ }_{\text {count }}$ value of 6.138 with significance equal to $0.000<0.05$ and regression coefficient value (b) equal to 0.573 (positive), hence can be concluded that spiritualbased leadership has a positive and significant effect on employee performance. The better the spiritual-based leadership is applied the higher the employee performance.

Leadership theorists, both sociologically and managerially, have offered various theories of leadership, including trait theory, behavioral theory, and situational-contingency theory (Sudharma, 2014). The trait theory or also called genetic theory is a theory that explains that the existence of a leader can be seen and assessed based on traits that are brought from birth as something inherited. Behavioral theory or also called humanistic theory is a theory that basing its assumption that leadership should be viewed as a relationship among people, not as the traits of an individual. While situationalcontingency theory assumes that the born of a leader is through social evolution by utilizing his ability to work and act to overcome problems that arise in certain situations and conditions.

Spiritual-based leadership is a combination of these three leadership theories. It is assumed that spiritual-based leadership not only requires a certain set of traits, characteristics, or temperaments that guarantee the success of any situation, but spiritual-based leadership must also pay attention to the leader's behavior as the action and response of his group he leads in reaction. Therefore, the success of a leader is determined by the leader's ability to connect and interact with his members. In addition, the success of a leader can also be shown in giving and encouraging spirit to all of his members in any situation and condition to do everything that is best.

Merriam Webster quoted by Frisdiantara (2012) argues that spirituality is to have an understanding of something related to the spirit and the sacred. Spirituality is also very closely related to the concept of the soul, thus determining a principle that the essence of life is not mere matter but its spiritual value. Therefore, spirituality without soul is absurd. This is because the concept of the soul is used to distinguish between humans and animals, which in the animal world will not speak of human values, mercy, and conscience, or represented in a word called the soul.

Workplace spirituality has actually grown over the years in business organizations such as team spirit, competitive spirit, cooperative spirit, and entrepreneurial spirit has become part of an interesting theme in some business organizations. It is recognized or not that the spirit of these workers has a direct effect on the productivity or performance of the workers. That way, organizations are willing to spend large amounts of money just to create a comfortable, fun, and even luxurious work environment. Moreover, today a number of recognition and compensation has been offered by the organization. So that spirituality in the workplace is not just a concept, but becoming a practical method for achieving success of organizational business (Frisdiantara, 2012).

In relation to spiritual-based leadership, spiritual-based leadership needs to absorb every activity, every attitude, and every individual behavior that exists within the organization, in terms of transactions or interactions within the organizational and administrative context (Frisdiantara, 2012). According Kaya (2015), spiritual-based leadership is a leadership that brings the worldly dimension to the divine dimension, and more relies on spiritual intelligence in leadership activities. Spiritual-based leadership is also a leadership that greatly maintains ethical values and divine values.

These result is in line with the research of Devi (2015) which proves that there is a positi- 
ve and significant relationship between the quality of spiritual leadership, spiritual survival with commitment and work productivity of employees in the organization.

The result of this study is also in accordance with the opinion of Frisdiantara (2012) that each organization is expected to be able to develop the concept of leadership towards highlevel knowledge that can open the spirituality. Spirituality is meant here is something very closely related to the concept of the soul, thus determining a principle that the essence of life is not mere matter but there is spiritual value. The result of this study also agree with Kaya (2015) that it is time for spiritual-based leadership to run.

Spiritual-based leadership is a leadership that brings worldly dimension to the divine dimension, and more relies on spiritual intelligence in its leadership activities. Or in other words, spiritual-based leadership is a leadership that greatly maintains ethical values and divine values. By upholding ethical values and divine values, this leadership can lead to better work or performance.

\section{CONCLUSIONAND RECOMMENDATION}

Based on the result of research and discussion can be concluded that the spiritual-based leadership has a positive and significant effect on employee performance at BMT in Semarang City is proven to be accepted. This means that spiritual-based leadership can be said to have a role as a predictor in improving employee performance because spiritual-based leadership which has characteristics: honesty of heart, fairness, self-knowledge, altruistic focus, non-dogmatic spiritualism, work more efficiently, generating the best in oneself and others, openness accepting the change, discipline, flexible, relax, smart, and humble, in fact it has a positive contribution to improve employee performance.

It can be interpreted that the better the spiritual-based leadership applied at BMT in Semarang City the higher the employee performance. For the next, The reseach can develope to improve performance by another variable. The variable like another leadership style and spiritual motivation.

\section{REFERENCES}

Aydin, B \& Ian, A. C. 2009. A Research Analysis on Employee Satisfaction in terms of Organizational Culture and Spiritual Leadership. International Journal of Business and Management. 4 (3):159-168.

Buble., Mario., Juras., Ana \& Matic., Ivan. 2014. The Relationship Between Managers' Leadership Style and Motivation. Management. $19(1): 161-193$.

Devi, U. 2015. Spiritual Leadership and its Relationship with Quality of Work Life and Organizational Performance - An Exploratory Study. Proceedings of the Second European Academic Research Conference on Global Business, Economics, Finance and Banking (EAR15Swiss Conference). 3-5.

Evans, L. 2007. Developing Research Cultures and Researchers in HE: the Role of Leadership. Proceedings. Annual Conference of the Society for Research into Higher Education (SRHE) December 11th 2007, submission no. 0132.

Frisdiantara, C. \& Sahertian, P. 2012. The Spiritual Leadership Dimension In Relation to Other Value-Based Leadership in Organization. International Journal of Humanities and Social Science. 2 (1): 284-290.

Hakim L., 2011. Pengaruh Gaya Kepemimpinan Terhadap Kinerja PNS Melalui Motivasi pada Dinas Perhubungan Kota Palembang. ILMIAH. 3 (3).

Kaya, A. 2015. The Relationship between Spiritual Leadership and Organizational Citizenship Behaviors: A Research on School Principals' Behaviors. Educational Sciences: Theory of Practice. 15 (3): 597-606.

Kiswanto, M. 2010. Pengaruh Kepemimpinan dan Komunikasi Terhadap Kinerja Karyawan Kaltim POS Samarinda. Jurnal EKSIS. 6(1): 1267-1439.

Melchar, D \& Bosco., Susan, M. 2010. Achieving High Organization Performance through Servant Leadership. The Journal of Business Inquiry. 9 (1): 74-88.

Naile, I. 2014. The Role of Leadership in Employee Motivation. Mediterranean Journal of Social 
Siti Hidayah \& Sutopo / The Role of Spiritual-Based Leadership as...

Sciences. 5 (3): 175-182.

Nanjundeswaraswamy T. S \& Swamy. 2014. Leadership styles. Advances In Management. 7 (2): 57-63.

Oweyemi \& Ekwoaba. 2014. Organisational Culture: A Tool for Management to Control, Motivate and Enhance Employees' Performance. American Journal of Business and Management. 3 (3): 168-177.

Purwanto, A. Y .2012. Pengaruh Kepemimpinan dan Motivasi Terhadap Kinerja PPL di Dinas Pertanian Daerah Kabupaten Nganjuk. Jurnal Ilmu Manajemen. REVITALISASI.1(2) September 2012.

Raharjo., C. D \& Witiastuti, R. S. 2016. Pengaruh Kepemimpinan Transformasional terhadap Keterikatan Kerja Melalui Keadilan Organisasional sebagai Variabel Mediasi. Management Analysis Journal. 5 (4): 347-361.

Rawung, F. H. 2013. The Effect of Leadership on the Work Motivation of Higher Education Administration Employees (Study at Mana- do State University). IOSR Journal of Business and Management (IOSR-JB). 15 (1): 28-33.

Soegihartono, A. 2012. Pengaruh Kepemimpinan dan Kepuasan Kerja Terhadap Kinerja dengan Mediasi Komitmen di PT Alam Kayu Sakti Semarang. Jurnal Mitra Ekonomi dan Manajemen Bisnis. 3 (1): 123-140.

Sudharma, K. 2014. Profesional Behavior Based on The Development of Employees. Jurnal Dinamika Manajemen. 5 (1): 1-11.

Thamrin, H. M. 2012. The Influence of Transformational Leadership and Organizational Commitment on Job Satisfaction and Employee Performance. International Journal of Innovation, Management and Technology. 3 (5): 566-572.

Timothy, Obiwuru. 2011. Effect of Leadership Style on Organizational Performance a Survey of Selected Small Scale Enterprises in Ikosi-Ketu Council Development Area of Lagos State, Nigeria. Australian Journal of Business and Management Research. 1 (7):100-111. 